\title{
格子型砂防ダムの土石流捕捉過程に関する 実験的研究 \\ EXPERIMENTAL STUDY ON DEBRIS FLOW CAPTURING PROCESS OF GRID TYPE SABO DAM
}

\author{
宮沢直季1・谷島＼cjkstart亨2・砂田憲吾3 \\ Naoki MIYAZAWA, Toru TANISHIMA and Kengo SUNADA \\ 1正会員 工修 山梨大学大学院助手 医学工学総合研究部（广400-8511 山梨県甲府市武田4-3-11） \\ ${ }^{2}$ 正会員 修 (工） 山梨大学研究生 土木環境工学科（广400-8511 山梨県甲府市武田4-3-11） \\ 3フェロー会員 工博 山梨大学大学院教授 医学工学総合研究部（T400-8511 山梨県甲府市武田4-3-11）
}

\begin{abstract}
The debris flow capturing process of the grid type sabo dam was clarified experimentally. The process could be explaned as follows; the dam was blocked by debris flow and the sediments deposited upstream of dam. The blocking was affected by the three-dimensional interlocking of gravel near the open spaces. After the blocking of dam, the incoming debris flow jumped due to the collision with the deposited layer. Then, the jumped sediments were divided into the sediments which got over the dam and the ones which returned back and deposited. Then, incoming debris flow ruched over the dam accompanying with the erosion of deposited layer. The debris flow discharged from dam and deposited upstream of dam intermittently by such a process. The separation of sands and gravels occurred by the deference of repulsion force in the process of debris flow jumping and the gravels deposited above sands, that is, the reverse-grading phenomenon of deposition.
\end{abstract}

Key Words : stony debris flow, grid type sabo dam, intermittent flow from dam, intermittent deposition upstream of dam, 3D interlocking of gravel, reverse-grading phenomenon of deposition

\section{1. はじめに}

砂防ダムは土石流対策，流送士砂調節のために有効な 砂防施設である．従来の砂防ダムの多くは，ダム上流部 で河床勾配を緩和させて土砂を堆積させる，不透過型の ダムであった. しかしながら，わが国では，土砂がダム 下流に十分に供給されず，それゆえ，河床低下，海岸線 の後退, 橋脚の洗掘など深刻な問題が生じている. また, 河川環境の視点から, ダムによって魚類・水棲生物の上 下流への往来ができないという問題も指摘されている. そのため最近では，河川流域における総合土砂管理の下 で, 水系全体としての適正な土砂移動のバランスを回復 し，かつ効率的な対応を図ることを目的とし，その一環 として鋼製格子型砂防ダム（図-1），鋼製スリットダム 等の透過型砂防ダムの設置，また既設の不透過型コンク リートダムのスリット化など土砂を流すダム事業が推進 されている.これらの透過型ダムの利点として, 土石流 発生時，巨砅が先頭部に集まる性質を利用して，巨砅が
透過部を閉塞することによって土石流を堆積させること， 平常時, 中小出水時における土砂を下流へ通過させるこ となどが挙げられる．流域全体の土砂のバランスを保つ ためにも，透過型砂防ダムの土石流捕捉効果の定量的な 評価が望まれる．そりためには土石流の捕捉のメカニズ ムとその後の土砂流出過程の両面から検討すべきである が，透過を前提としている形式ではまずは，捕捉過程や その効果を明らかにする必要がある.

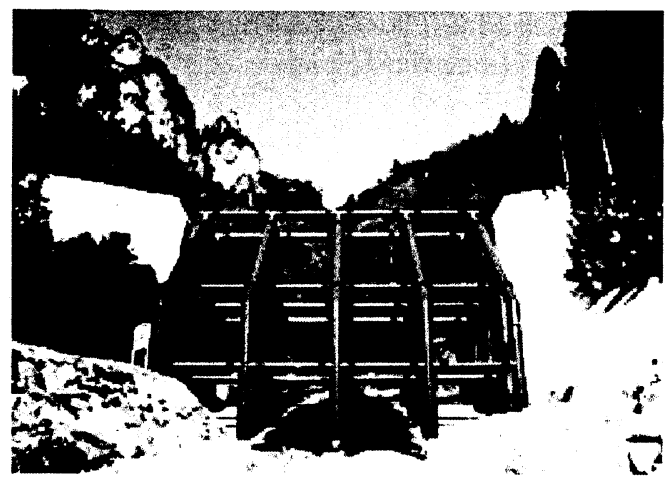

図-1 鋼製格子型砂防ダム 


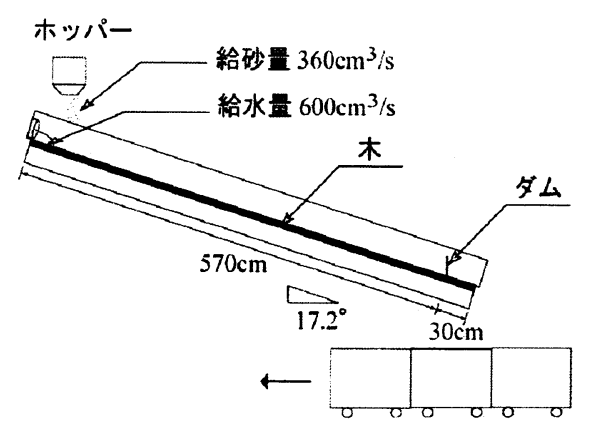

図-2 実験水路

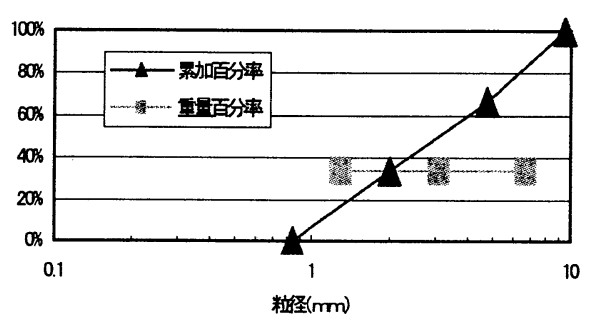

図-3 粒度分布

芦田・高橋 ${ }^{1)}$ による格子型砂防ダムの土石流調節に 関する実験的研究では, $\mathrm{L} / \mathrm{d}_{\max }=1.5 \sim 2.0$ のとき（Lは透過 部の間隔， $\mathrm{d}_{\max }$ は最大粒径），格子型砂防ダムが土石流 を効果的に捕捉すると述べている．また，水山ら ${ }^{2) ，}$ Mizayama and Mizmo ${ }^{3)}$ は格子型砂防ダムの捕捉・減勢さ せる効果に影響を与える要因として $\mathrm{Ld}_{\max }$ に加えて, 土 石流先頭部の砂砂の容積濃度を挙げている。 一方, 水野 ら ${ }^{4)}$ は連続して配置した格子型砂防ダムによる土石流 捕捉効果を検討し, 捕捉のためには上流側の透過部分よ り下流側の透過部分を小さくする必要があると述べてい

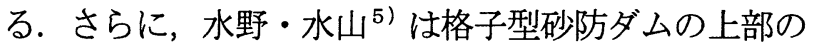
格子間隔を狭くした方がダムの土石流捕捉効果を向上さ せるこよを述べている. いずれの研究においても，土石 流がどのようなメカニズムによって格子型砂防ダムによ って捕捉されるのか, ダムからどのような粒径の土砂が 流出するのか，またダムによって捕捉された土砂がどの ような粒径の土砂で構成されるのかについては十分明ら かにされていない.

そこで, 本研究では, 格子型砂防ダムの機能に着目 し, 実験を通して土石流捕捉効果および捕捉状況等を把 握する.

\section{2. 実験概要}

最大礫径 $2 \mathrm{~m}$ ，計画土石流流量の約1.6倍の土石流が実 際の鋼製格子型砂防ダムに捕捉される場を想定して実験 条件を決定した. 想定したダムは釜無川右支川小武川の 上流部にある大棚沢第二ダムである. 計画土石流諸元は， 元河床勾配が $\mathrm{i}=1 / 5.7\left(10^{\circ}\right)$ ， 最大粒径が $\mathrm{d}_{\max }=2 \mathrm{~m}$, 設計土石流水深が $\mathrm{h}=3 \mathrm{~m}$ ，土石流の流速が $\mathrm{U}=7.24 \mathrm{~m} / \mathrm{sec}$
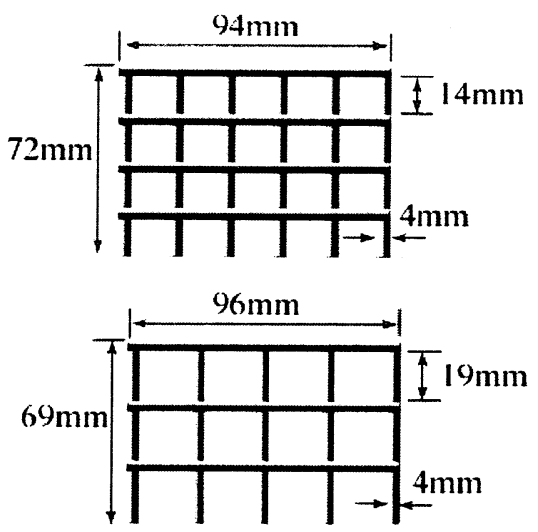

図-4ダム模型 (上が $/ \mathrm{d}_{\max }=1.5$, 下が $\left.\mathrm{L} \mathrm{d}_{\max }=2.0\right)$
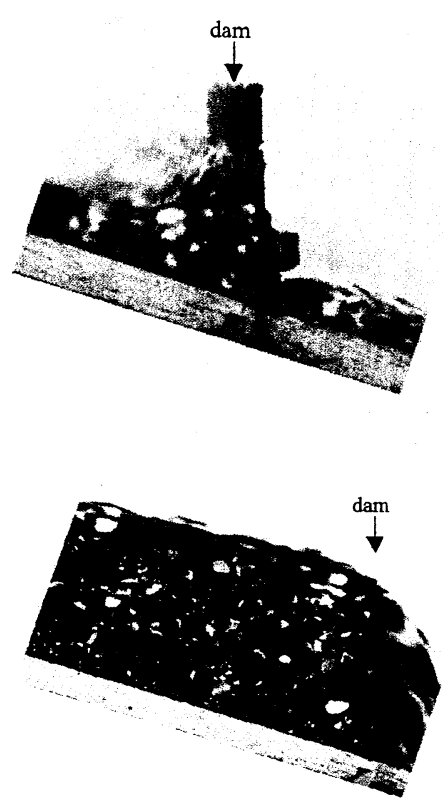

図-5 流動状況の違い（上の写真が土石流がダムに到達してか ら0.5秒後, 下の写真が5秒後, $\left.\mathrm{L} \mathrm{d}_{\mathrm{max}}=2.0\right)$

である ${ }^{6)}$. ダム諸元は，ダム高さがH=14.5m，ダム幅が $\mathrm{B}=69 \mathrm{~m}$ ，水通り幅が $\mathrm{Be}=17.8$ mである. 水通し部におけ る格子間隔は $\mathrm{L}=4 \mathrm{~m}\left(\mathrm{~L} / \mathrm{d}_{\max }=2.0\right)$ である.

図-2に実験水路を示す．水路長 $600 \mathrm{~cm} ，$ 幅 $10 \mathrm{~cm}$ ，高さ $22 \mathrm{~cm}$ ，水路勾配 $17.2^{\circ}$ のアクリル製水路に，高さ $10 \mathrm{~cm} の$ 所に木製の板を敷いた. 上流から水と土砂を20秒間供給 することにより土石流を発生させ，下流端で水と土砂を 採取した。採取方法は以下の通りである．図-2のように レールの上に 5 つの滑車付き採取箱を載せ，約 3.3 秒ご とに速やかに箱を移動させて水と土砂を採取した。 土砂 は0.84 9.52mmの混合粒径を使用して，上流端から $50 \mathrm{~cm}$ の位置にあるポッパーから給砂した。 ポッパーに入れる 土砂の粒度分布は図-3に示すとおりである。.また，下流 端から $30 \mathrm{~cm}$ の位置に一面の格子型ダム（真鍮製）を配 置した. 格子型ダムの寸法は図-4に示すとおりで，大棚 沢第二ダムのUd $\mathrm{d}_{\max }=2.0$ （幾何縮尺1/210）とそれよりも格 子間隔の狭い $U / \mathrm{d}_{\max }=1.5$ としている．模型のダム高は大棚 沢第二ダムのダム高さと幾何縮尺より定めた． 給水量は 

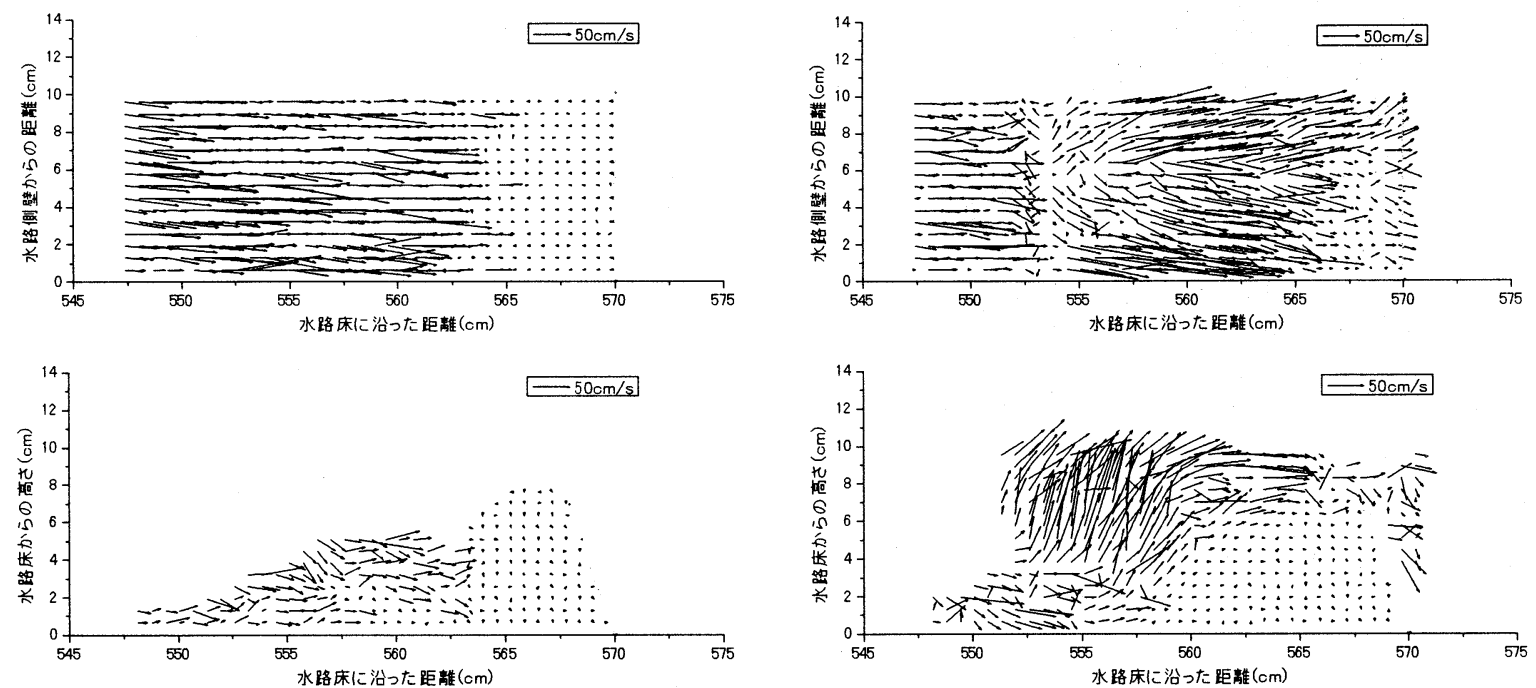

(a) $t=1.5 \mathrm{sec}$

(b) $\mathrm{t}=2.0 \mathrm{sec}$
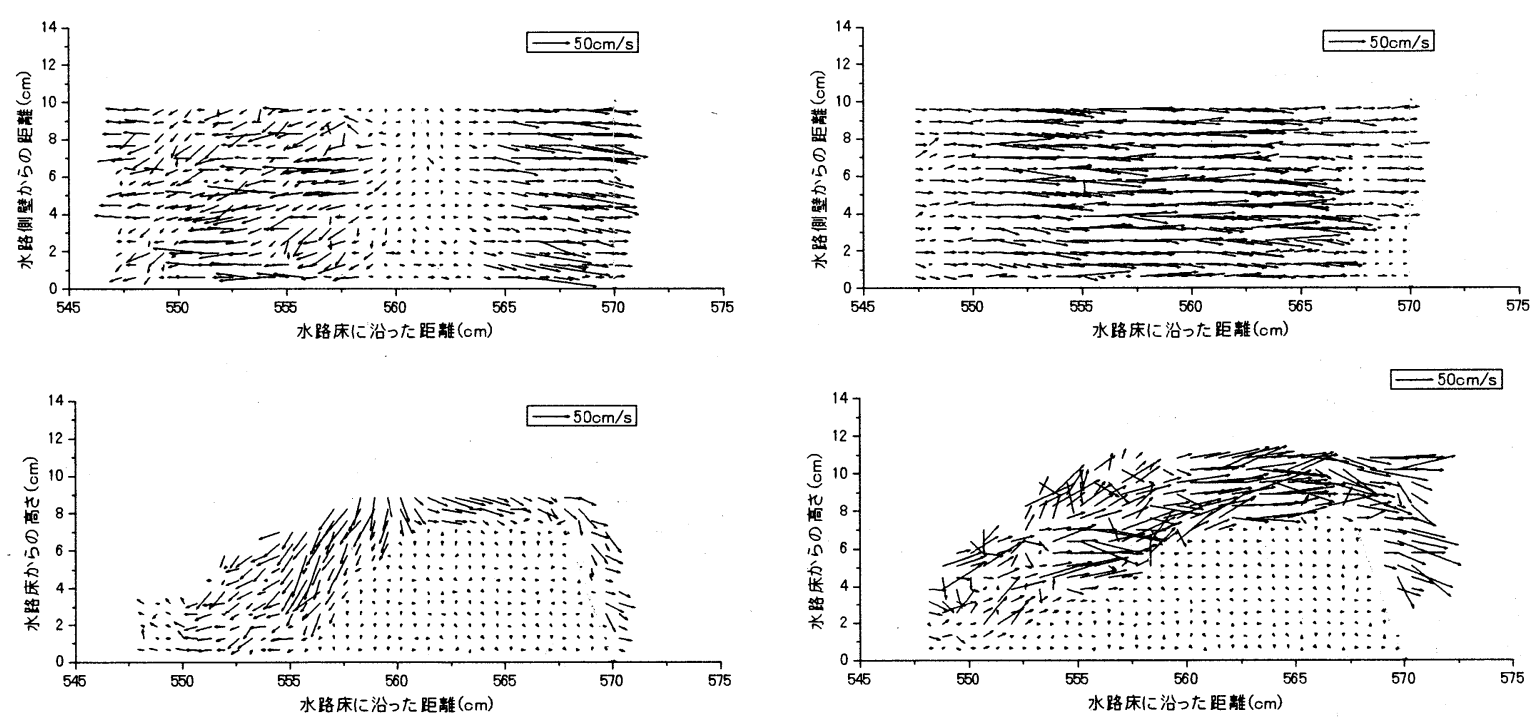

(c) $t=2.5 \mathrm{sec}$

(d) $t=3.0 \mathrm{sec}$
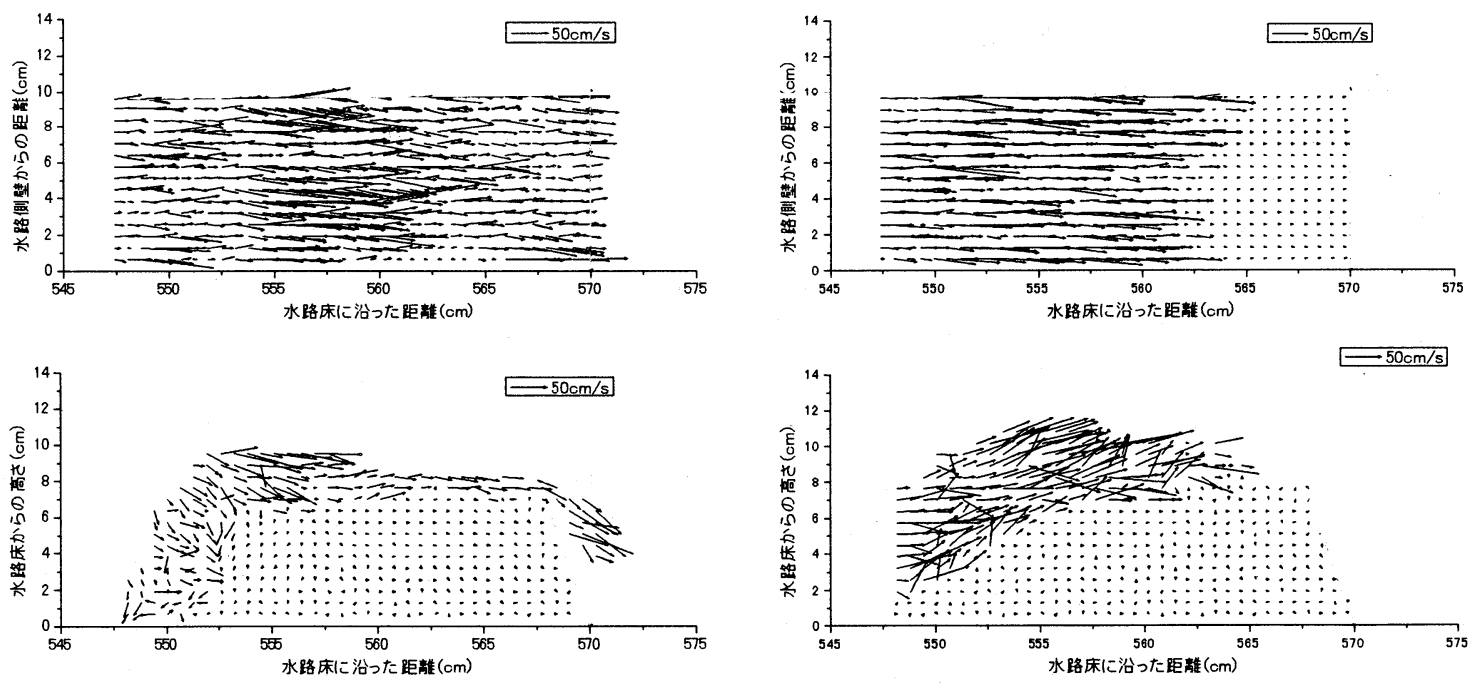

(e) $\mathrm{t}=3.5 \mathrm{sec}$

(f) $\mathrm{t}=4.0 \mathrm{sec}$

図-6 ダム付近の流動・堆積状況（ $\mathrm{L} / \mathrm{d}_{\max }=1.5$ のケース）, 縦断図の縦軸は水路床に対して直角方向の高さを示す. 


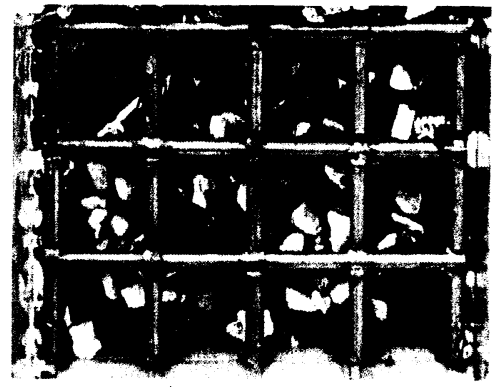

図-7 透過部近くの礫の 3 次元的噛み合わせ $\left(U / d_{\max }=2.0\right)$

$600 \mathrm{~cm}^{3} / \mathrm{s}$, 給砂量は $360 \mathrm{~cm}^{3} / \mathrm{s}$, 土石流流量は $960 \mathrm{~cm}^{3} / \mathrm{s}$ であ る. フルードの相似則を用いると，この流量は $610 \mathrm{~m}^{3} / \mathrm{s}$ と なり, 計画土石流流量 $387 \mathrm{~m}^{3} / \mathrm{s} の 1.6$ 倍に相当する. 計測 項目として，下流端から流出した水と土砂，格子型ダム によって捕捉された土砂量, 格子ダム付近を側面と上部 よりCCDビデオカメラで同時に撮影した.

\section{3. 実験結果及び考察}

\section{（1）土石流の捕捉過程}

図-5に格子ダムが $d_{\max }=2.0$ のケースの流動状況を示す. 上の写真が土石流先頭部がダムに到達してから 0.5 秒後, 下の写真が 5 秒後の流動状況を示す. 0.5 秒時には, 土 石流は完全に捕捉されずダムの透過部から土砂が流出し ているのがわかる．0.5秒後の時刻における流動状況か ら判断すると，土砂がダム頂まで捕捉されるのに $1 \sim 2$ 秒かかり，その後，土石流は図-5の下の写真で明らかな ようにダムの上を流動する.

図-6に $\mathrm{L} / \mathrm{d}_{\max }=1.5$ のケースのダム付近の土石流の流動・ 堆積状況を示す．礫粒子の瞬間速度ベクトルは，1/30秒 間隔で得られた2枚のデジタル画像を用いて，相関法7) によって計算されたものである．それぞれの時刻の上図 が水路床に対して直角方向に上から撮影された画像から， 下図が水路床に沿って横から撮影された画像から出した ものである．1.5秒時では，土石流が礫の噛み合い（図一 7）によりダムによって捕捉され，すぐにダム頂まで土 砂が堆積する. 急な勾配で堆積した土砂に上流からの土 石流が衝突しようとしているのがわかる．2秒時では， 土石流が堆積層との衝突によってジャンプし，堆積層の 上を覆い被さるように流動する．2.5秒時では，2秒時 にジャンプした土砂が重力によって落ちてきて，560cm 付近でそのままダムの上を流れていく土砂と，上流に向 かって落ちて戻ってきた土砂に分けられ，この時土砂の 堆積が起こる．上から見た場合にも560 $\mathrm{cm}$ 付近でその現 象が確認できる．3秒時では，上流から流下してきた土 石流が土砂を侵食しながら一気に堆積面を乗り越える様 子を表している．3.5秒時には，2.5秒時のようにダムを 乗り越える土砂と戻ってくる土砂に分断されているのが
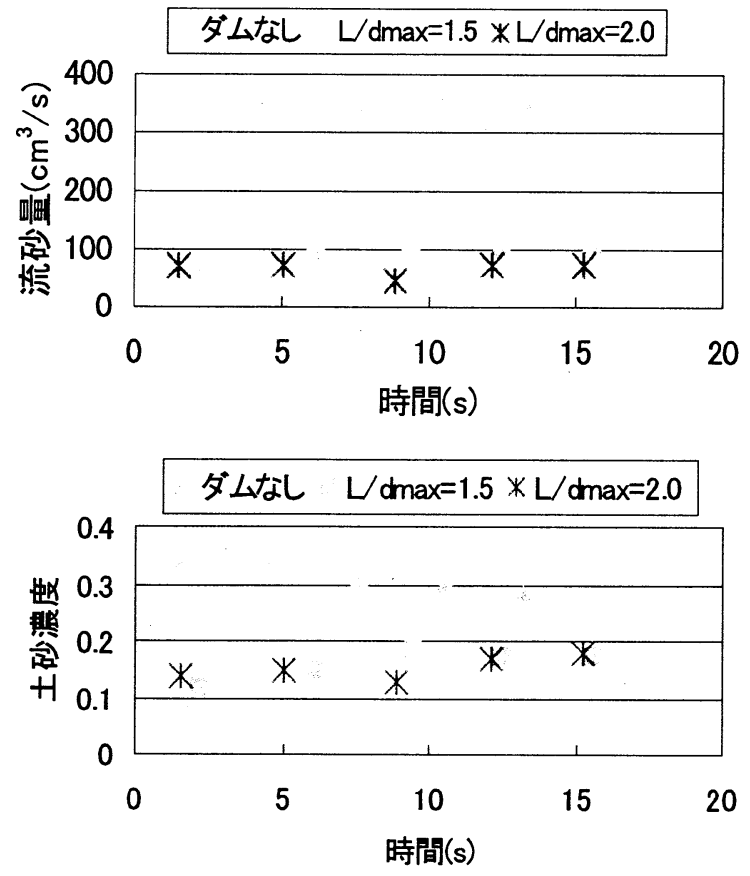

図-8 ダム下流の流砂量及び体積土砂濃度

確認できる．4秒時は，3秒時のように落ちて戻ってき た土砂が堆積し，上流から流動してきた土石流が土砂を 侵食しながら一気に堆積面を乗り越える様子を表してい る. 土石流はこのようなメカニズムで間欠的に格子ダム から流出し，同時にダムの上流に堆積する.

図一7は給水・給砂終了後にダムを正面から撮影した写 真である. ダム近くで捕捉された土砂はほとんど粒径の 大きい土砂からなり，下部を見ると，アーチ状に土砂が 捕捉されていることがわかる．格子型砂防ダムの透過部 分の閉塞は礫の3次元的なアーチ状の噛み合わせに因る と言える.

\section{（2）ダム下流の流砂量及び体積土砂濃度}

図-8にダム下流の流砂量及び体積土砂濃度を示す。土 砂がダムによって捕捉されるため，ダムのないケースと 比べて流砂量及び土砂濃度は少なくなっている。また， 流砂量も土砂濃度も時間によってあまり変化しないで, ほぼ一定値と見てよい（前述のように土石流はダムから 間欠的に流出するが，実験值はその採取時間（平均で 3.3秒）の平均的な值を示すことに注意する必要があ る）。ダムがある場合の流砂量をP，ダムがない場合の 流砂量を $\mathrm{P}_{0}$ として通過率を $\mathrm{P} / \mathrm{P}_{0}$ で定義する． $\mathrm{L} / \mathrm{d}_{\max }=2.0$ の 場合，通過率は 0.19 ，捕捉率は $0.81 て ゙ あ り ， L / d_{\max }=1.5$ の場 合，通過率は0.26，捕捉率は0.74である．図一6から，1.5 秒時や 4 秒時ではダムから越流する土砂はほとんどなく， 一方，3秒時ではダムからの越流流砂量は極めて高い． このような流砂量の間欠性が時間が経過しても同じよう に起こることを図-8は示している. 図-6のケースでは, 間欠性の周期は $1 \sim 1.5$ 秒であると判断される. 


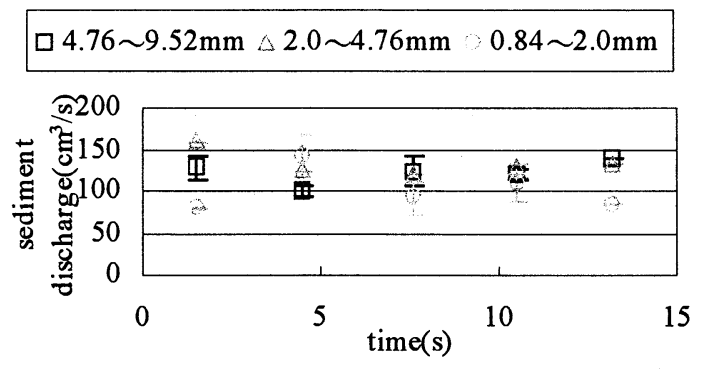

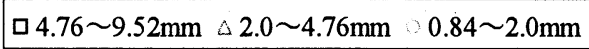

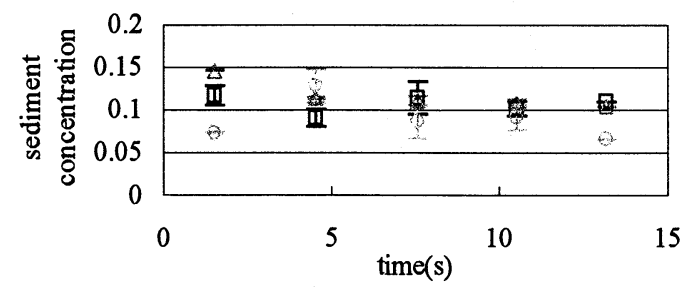

図-9 ダム下流の粒径別の流砂量及び体積土砂濃度 （ダムがない場合）
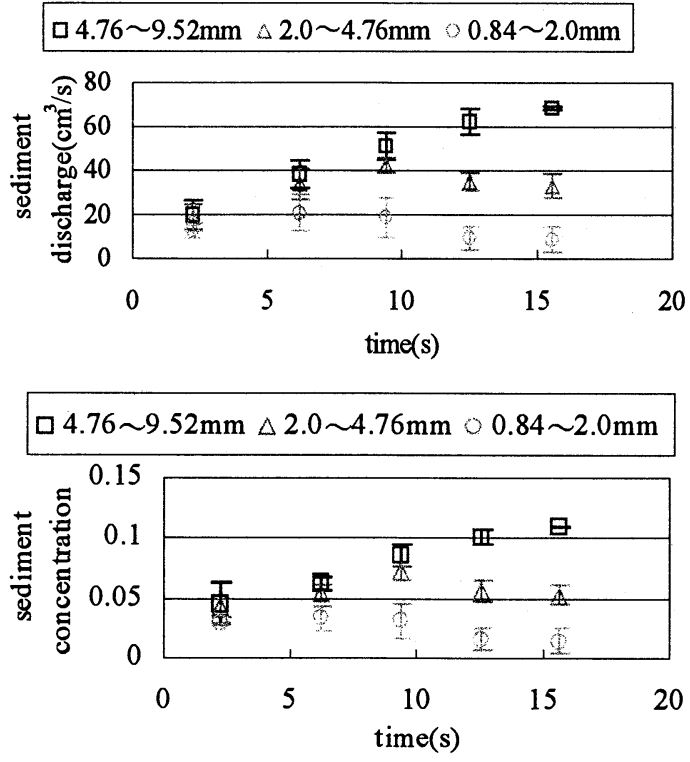

図-10 ダム下流の粒径別の流砂量及び体積土砂濃度 $\left(\mathrm{U} / \mathrm{d}_{\operatorname{mxx}}=1.5\right.$ の場合 $)$

ダム高が実験に用いたものよりも低くなると，ダムか ら流出する土砂量は多くなる，間欠的に流出するが，流 砂量の変動は小さくなることが予想される. ダム高の違 いが捕捉現象にどのような影響を及ぼすかは今後検討す る必要がある。

図-9にダムがない場合の粒径別の流砂量および体積土 砂濃度を示す，土石流には先頭部に巨砅が集まる性質が あるが，本実験では先頭部において碟が多くなることは 明瞭に見られなかった。 また, 先頭部は土砂濃度が高い とされるが，本実験ではこの傾向は見られなかった.

図-10に $\mathrm{L} \mathrm{d}_{\max }=1.5$ のケースの粒径別の流砂量及び体積 土砂濃度を示す. 初期には格子ダムを閉塞する前に, 土 石流が透過部を通過するため, どの粒径の流砂量および

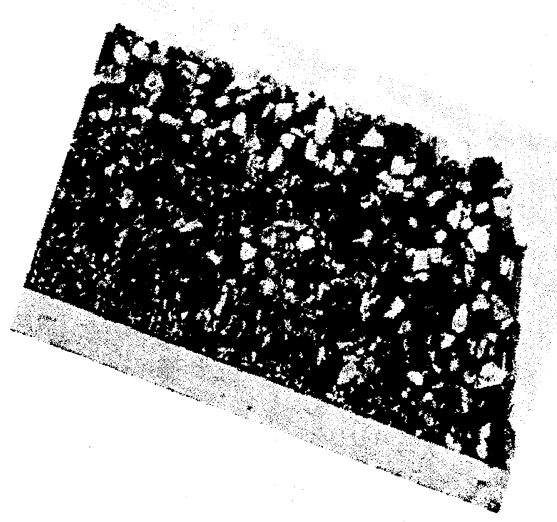

図-11 堆積の逆グレーディング現象

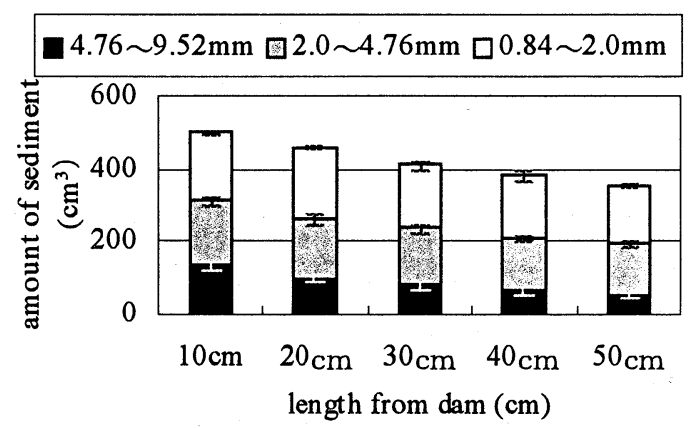

$4.76 \sim 9.52 \mathrm{~mm}$ 固 $2.0 \sim 4.76 \mathrm{~mm} \square 0.84 \sim 2.0 \mathrm{~mm}$

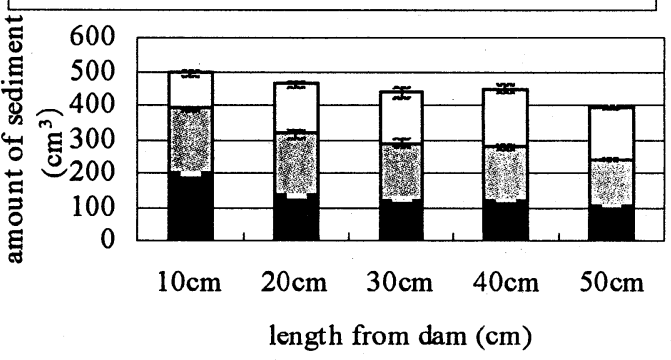

図-12 堆積土砂の容積（上 : $\mathrm{L} / \mathrm{d}_{\max }=1.5$, 下 : $\left.\mathrm{L} / \mathrm{d}_{\max }=2.0\right)$

土砂濃度もほとんど変化しない，それ以後は，格子ダム は土砂によって閉塞され，土石流は堆積層の上を流出す る. 時間が経過するにつれて，4.76〜9.52mmの粒径の流 砂量と土砂濃度は増加し, 逆に0.84〜2.0mmの粒径の流 砂量と土砂濃度は减少する. 土石流が堆積層との衝突に よってジャンプするとき, 砂と礫の分離が起こったと考 えられる. 礫の反発力は砂の反発力よりも大きいので, 礫は砂よりもより高くジャンプする. その結果, 落ちて 戻ってきた際，下部の方は砂が堆積し，上部になるほど 砅が堆積する，いわゆる堆積の逆グレーディング現象

（図-11）が起こる. したがって，堆積表面近くの礫は 上流ふらの土石流によって侵食され，ダム下流の磉の流 出量が多くなると考えられる.

\section{（3）ダムによって捕捉される土砂}

図-12に格子ダムより上流に堆積した土砂の容積を $10 \mathrm{~cm}$ 区間ごとに示寸．上図がL/ $\mathrm{d}_{\max }=1.5$ のケースであり, 下図が $\mathrm{d}_{\max }=2.0$ のースである.これらの図から，格子 

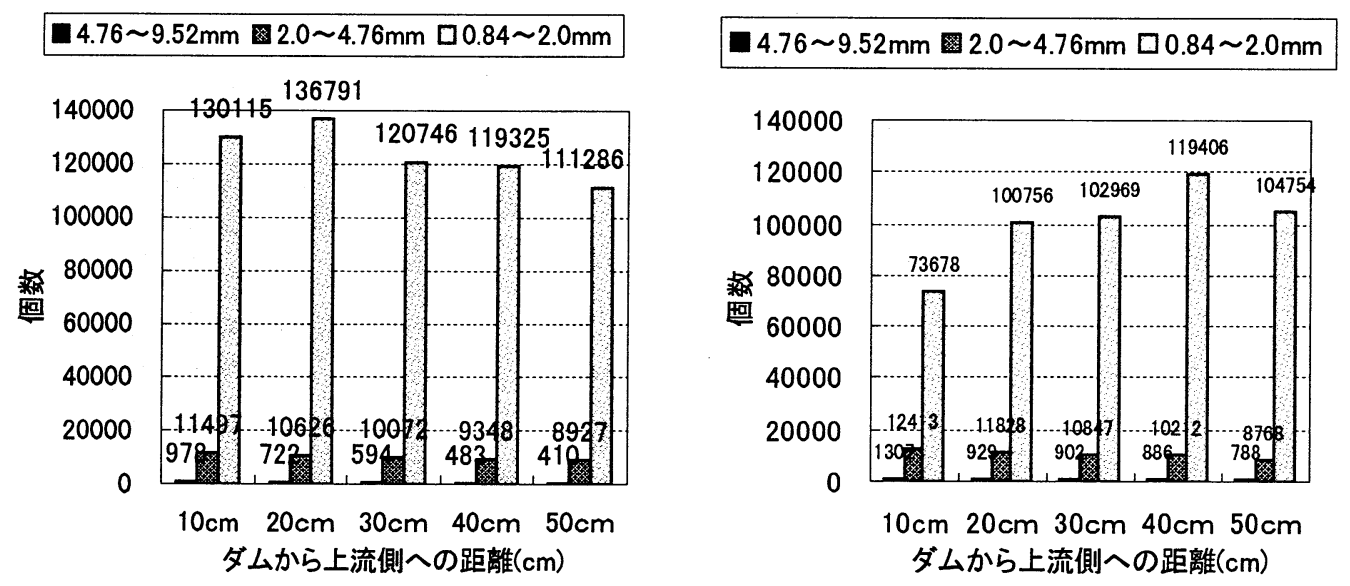

図-13 堆積土砂の個数表示 (左 : $\mathrm{L} / \mathrm{d}_{\mathrm{max}}=1.5$, 右 : $\mathrm{L} \mathrm{d}_{\mathrm{max}}=2.0$ )

ダムに近づくほど粒径の大きいものが多いことがわか る. $\mathrm{L} / \mathrm{d}_{\max }=1.5$ のケースでは， $0.84 \sim 2.0 \mathrm{~mm}$ 及び $2.0 〜$ 4.76mmの粒子の土砂の容積はどの区間でも変化がなく, 全体の堆積士砂のかなりの部分を占める. 逆に, 4.76〜 $9.52 \mathrm{~mm}$ の土砂の割合は低い. $L / \mathrm{d}_{\max }=2.0$ のケースでは, $\mathrm{L} \mathrm{d}_{\max }=1.5$ のケースと比べて,4.76 9.52mmの粒径の土砂が 全体の堆積土砂に占める割合は高い．また,ダムに近い ほど0.84〜2.0mmの土砂の容積は少なくなっている. 格 子間隔が大きい場合には,堆積土砂は主に粒径の大きい 礫で構成される. 堆積層の上を流動する土石流内の水 は容易に堆積層に浸透する．浸透した水が礫の間䏚に 存在する砂をダムの透過部を通って流出させる. 図-13 は堆積した土砂量を個数表示したものである. 堆積し た土砂量を粒径階の平均粒径の球の体積で割った值で ある.この図でも $\mathrm{L}_{\mathrm{d} \max }=1.5 て ゙ は 0.84 〜 2.0 \mathrm{~mm}$ の粒子の個 数はダム付近でもかなり多く, $\mathrm{L} / \mathrm{d}_{\max }=2.0$ ではダムに近い ほど0.84〜2.0mmの粒子の個数が少なくなっている.

\section{4. 結論}

最大礫径 $2 \mathrm{~m}$ ，計画土石流流量の約1.6倍の土石流が実 際の鋼製格子型砂防ダム（大棚沢第二ダム）に捕捉さ れる場を想定して実験を行い, ダム下流への流出量, ダムの捕捉量の計測およびビデオ画像解析により，格 子型砂防ダムの土石流捕捉過程およびその効果につい て考察した。得られた主な結論は以下のとおりである.

1) $\mathrm{L} / \mathrm{d}_{\max }$ (Lは格子間隔， $\mathrm{d}_{\max }$ は最大粒径）が1.5と2.0の のケースでは，格子型砂防ダムが74〜81\%の土砂を 捕捉することがわかった。

2) 格子型砂防ダムの閉塞は,透過部近くの碟の 3 次元 的なアーチ状の噛み合わせによって生じることが確 認できた.

3）土石流の捕捉過程が明らかとなった. すなわち，ダ ムが閉塞した後は，土石流が流れ方向に対して急勾
配に堆積した土砂との衝突によってジャンプし，ダ ムを乗り越えて流出する土砂と上流方向に戻り，堆 積する土砂とに分断される. 上流からの土石流は堆 積層を侵食しながらダムを乗り越えて流出する．土 石流はこのようなメカニズムで間欠的に格子ダムか ら流出し，格子ダムの上流に堆積する.

4) 土石流が堆積層との衝突によってジャンプするとき, 砂と碩の分離が起こり, 礫は砂の上に堆積する（堆 積の逆グレーディング現象）．堆積表面近くの砅は 流下してきた土石流によって侵食され，多くの碩が ダムの下流一流出する.

5）ダムの上流に堆積した土砂はダムに近いほど礫分が 多く, 格子間隔が大きいほど全体として礫分が多い.

\section{参考文献}

1)芦田和男, 高橋 保 : 土石流の調節制御に関する研究, 京都 大学防災研究所年報, 第23号B-2, pp.433-441，1980.

2)水山高久，小橋澄治, 水野秀明 : 格子型ダムのピーク流砂量 減少率に関する研究，新砂防，Vol47, No.5, pp.8-13, 1995.

3)Miziyama, T. andMizuno, $\mathrm{H}$ :Prediction of debris flow hydrograph passing through grid type control structure, Proceeding of the First Intemational Conference on Debris-Flow Hazards Mitigation: Mechanics, Prediction, and Assessment, pp.74-82, 1997.

4)水野秀明，南 哲行，水山高久 : 連続して配置した鋼管製透 過型ダムに上る土石流の捕捉効果に関する実験的研究，砂 防学会誌, Vol53, No.1, pp.19-25, 2000.

5)水野秀明，水山高久：上部の格子間隔が狭い格子型ダムに関 する研究，砂防学会誌，Vol49, No.4, pp.3-8, 1996.

6) 瀬戸俊彦，葛西俊一郎，山口健太郎，水山高久 : 鋼製透過型 ダムによる砂磷型土石流の捕捉状況，砂防学会誌，Vol51, No.3, pp.19-26, 1998.

7) Miyazawa, N.: Flow behavior of head of stony debris flow on unsaturated erosible bed Proceedings of the $7^{\text {th }}$ Intemational Syposium on River Sedimentation, pp.293-301, 1998.

（2004.9. 30 受付） 